\title{
Institutional Collaboration on the Lake of Bakuok in Sustainable Management
}

\author{
Afrizal $^{1}$, Mayarni ${ }^{2}$, Mimin Sundari Nasution ${ }^{3}$ \\ ${ }^{1}$ International Relation, Faculty of Social and Political Sciences, University of Riau (email: \\ afrizalhiunri@gmail.com), ${ }^{2}$ Public Administration, Faculty of Social and Political Sciences, University of Riau \\ (email: Mayarni@lecturer.unri.ac.id), ${ }^{3}$ Public Administration, Faculty of Social and Political Sciences, University \\ of Riau Kampus Binawidya Km 12.5 Simpang Baru Panam, Pekanbaru 28293 (email: \\ mymien_031086@yahoo.com/mimin.sundari@lecturer.unri.ac.id)
}

\begin{abstract}
Lake Bakuok is a conservation area and traditional indigenous Lake or prohibition hole that has culture-based fishing activities, we can see this with the tradition of fishing together using nets that have become tourist destinations in Kampar Regency, Riau Province, in regional languages locally called "Ma'awuo". All activities carried out in this Bakuok lake is controlled by traditional authorities Kenegrian Tambang which has the same vision in the conservation and protection of the lake region. On the other side ecologically Bakuok lake is very alarming, with palm trees and rubber were planted alongside the lake, and the fish cages. Based on the rules regarding the ban on Lake Bakuok, not all of these rules are implemented and implemented properly, even though there are already those who supervise, there are still violations that occur. The number of institutions involved in the development of Lake Bakuok so far is still temporal or temporary, and runs each and has not formed a systematic collaboration. This study aims to see how institutional collaboration in Lake Bakuok sustainable management. The study uses qualitative research methods that aim to obtain a holistic picture of a phenomenon in the Bakuok Lake. The results showed several important items related to Lake Bakuok institutional collaboration, namely the type of network structured (network structure) that is still unclear and does not have a unified conceptual description of Lake management. The absence of Commitment to a common purpose. Trust among stakeholders is still lacking. The unavailability of standard provisions for clear procedures and responsibilities in the relevant institutions. Access to information of stakeholders who are not members as long as they can be accepted by all parties is still difficult.
\end{abstract}

\section{Keywords:}

collaboration; institutional; sustainable development

\section{Introduction}

Riau Province, exactly in Kampar Regency, Tambang District in Aur Sati Village, there is a lake called Lake Bakuok. Lake Bakuok is a conservation area (Conservat area) and Lake Adat or lubuk ban which has a culture-based fishing activity, this can be seen by the 
activity of catching fish in the local language called "mauwo" which has become a public party event that held once a year which was once allowed to catch fish only once every 2 months. All activities carried out in Lake Bakuok are controlled by the Kenegrian Tambang traditional stakeholders who share the same vision in the conservation and protection of the lake area.

The Ma'awuo event carried out has the potential to damage the Bakuok lake conservation area, because the activities carried out are contrary to the aim of making Bakuok Lake a conservation area and the depth of the larrangan that should be able to protect the fish in the Lake. Seen from the fishing gear used can capture habitat that is in the lake. In addition, ecologically there has been a physical change from flowing ecosystems (in the form of rivers) to inundated ecosystems (in the form of lakes). Even physically between the river and the lake has lost the ecological relationship, but the ecological relationship between the two can occur in the rainy season where river water overflows (flood).

The position of customary head and village head is equal and cooperates with each other in guarding Lake Bakuok. In this case, the adat head and ninik mamak have a role in making rules and prohibitions about the lake around Bakuok, while the village head has the role to coordinate any matters related to the interests of the Bakuok lake. Then the customary head and village head together with ninik mamak and the apparatus other villages hold meetings and form a group whose task is to manage and supervise the lake called the lubuk ban group, which consists of dubalang from 10 people per tribe. And finally the community also has a role in managing the lake in Bakuok, namely by together keep the lake so that the lake is maintained and protected from unscrupulous elements who catch fish carelessly.

The management of the Bakuok lake with a customary pattern, supported by the many institutions involved in managing the Bakuok lake. Ongoing collaboration certainly becomes systematic which will be collaborated, coupled with being made a conservation area allows for good collaboration with all stakeholders. The development of a managing organization that was initially simple can then develop. According to DeSeve quoted in the journal Ratna Trisuma Dewi (2012) there are several important items that can be used as a measure of the success of a network or collaboration in governance, including : 
a. Network structured type. Explain the conceptual description of a link between one element and other elements that come together that reflects the physical elements of the network being handled.

b. Commitment to a common purpose (commitment to the goal). Refers to the reason why a network must exist.

c. Trust among the participants (trust among stakeholders). The existence of mutual trust between the actors / participants arranged in the network is based on professional or social relations.

d. Governance. This includes mutual trust between the actors, there are limits on who can be involved and who should not be involved, and there are clear rules that are mutually agreed upon, and freedom to determine how collaboration is carried out.

e. Access to authority (access to power). Access to power, namely the availability of clear standards of procedure provisions which are widely accepted.

f. Distributive accountability / responsibility (division of accountability / responsibility). Share governance (governance, management, management together with other stakeholders) and share a number of decision-making with all network members; thus sharing responsibility for achieving the desired results.

g. Information sharing (access to information of stakeholders), namely ease of access for non-members as long as it is acceptable to all parties

h. Access to Resource (available resources). Availability of financial, technical, human and other resources needed to achieve network objectives.

Collaboration that is raised in the management of the raw lake, with a sustainable pattern of hope that the sustainability of the lake that touches on economic, environmental and social aspects. Seeing the importance of Lake Bakuok for the community in terms of the fisheries, economic, cultural and other sectors and to preserve fish resources, institutional measures are needed to support fish diversity and lake conservation areas. Based on the phenomenon described above, the researcher is interested in conducting a scientific study entitled "Institutional Collaboration on the Lake of Bakuok in Sustainable Management". 


\section{Research Methods}

This type of research model of the development of sustainable rawok lake in Kampar Regency is a qualitative research method, which is focused in Bakuok Lake, Aur Sati Village, Tambang District, Kampar Regency. Research informants in the research are: Customary Apparatus (ninik mamak), Village Head, Head of the Office of the Environment and Forestry Agency (DLHK) and several village communities. By collecting primary and secondary data through Interview, Observation and Literature Study Techniques. All data results are collected and studied so that it becomes a unified whole. Then for the validity of the results of this study, researchers used data triangulation techniques so that the activities of checking, re-checking and crosschecking the material or data with this observation were crosschecked through research perception. Activities in qualitative data analysis are carried out interactively and continue continuously until completion.

\section{Results and Discussion}

The management of Lake Bakuok aims to preserve the existing local wisdom and make this lake as a tourist destination. In the management of Lake Bakuok involves ninik mamak, village government and community. In this case Ninik mamak has a significant role in the management of Bakuok lake, all the rules are made by Ninik Mamak. In bakuok lake development, while institution whose role can be seen in Table 1 Institutional exist in managing the lake bakuok, consisting of many stakeholders, which has a function and contributions of each in managing the lake bakuok.

Table 1.

Institutional Contributions in the development of Lake Bakuok

\begin{tabular}{|c|c|c|}
\hline No & Institutional & Contributions \\
\hline 1 & $\begin{array}{l}\text { Ministry of Fisheries and } \\
\text { Maritime Affairs of the Republic } \\
\text { of Indonesia }\end{array}$ & $\begin{array}{ll}> & 1000 \text { fish seeds (catfish, gourami, lomac } \\
& \text { fish, motan fish (2015) } \\
> & 30,000 \text { Nilem Fish Seedlings (2018) } \\
> & 70,000 \text { Lomak fish seedlings (2018) }\end{array}$ \\
\hline 2 & Riau Province Fisheries Service & $>\quad 1000$ fish seeds (2016) \\
\hline 3 & Riau Province Tourism Service & 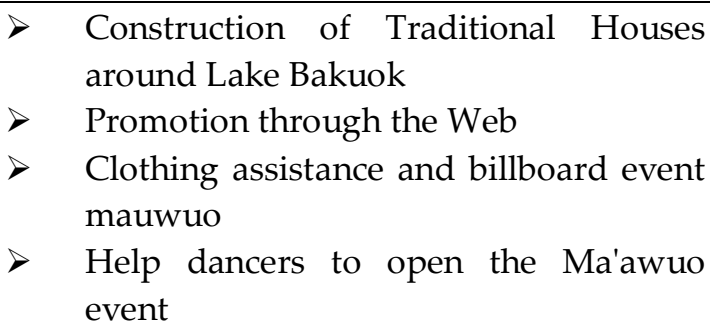 \\
\hline
\end{tabular}




\begin{tabular}{|c|c|c|c|}
\hline & & $>$ & Banner \\
\hline 4 & District Fisheries Service Kampar & $\begin{array}{l}> \\
> \\
>\end{array}$ & $\begin{array}{l}50 \text { tons of fish seeds }(2017) \\
5 \text { placards }(2017) \\
1000 \text { fish seeds }(2018) \\
6 \text { canoes }(2015)\end{array}$ \\
\hline 5 & District Tourism Service Kampar & $>$ & $\begin{array}{l}\text { Promotion through the Web and Social } \\
\text { Media }\end{array}$ \\
\hline 6 & LAM Riau & & \\
\hline 7 & Aur Sati Village & $>$ & $\begin{array}{l}\text { Territory } \\
\text { Planning and facilitating activities }\end{array}$ \\
\hline 8 & Ninik Mamak & & $\begin{array}{l}\text { Customary rules and laws } \\
\text { Facilitating Deliberation }\end{array}$ \\
\hline 9 & PTP N V & $>$ & $\begin{array}{l}\text { Loan assistance for lawn mowers every } \\
\text { month } \\
\text { Help clean lake water once a year }\end{array}$ \\
\hline 10 & PT. Hervania & & \\
\hline
\end{tabular}

\section{Sumber : Processed Researchers, 2019}

The table shows the institutional contribution to the development of Lake Bakuok, but this institutional contribution is still temporal or temporary and institutionally not well documented. On the other hand, ecologically Lake Bakuok is very alarming, with the presence of Palm and Rubber Trees planted alongside the lake, as well as the existence of fish cages. Based on the rules on the ban on Lake Bakuok, not all of the rules are implemented and implemented well, although there are already monitoring the lake there are also violations that occur. The number of institutions involved in the development of the raw lake so far, each runs and has not formed a systematic collaboration.

Lake Bakuok is set based on customary law, which rules about the surrounding Lake Bakuok are made directly by the customary chief or local ninik mamak which is a form of policy from the customary leader and ninik mamak in the village. In the results of the Ninik Mamak Kenegerian Mine-Terantang discussion, a decision and regulation was made regarding the ban on Lake Bakuok. The rules are as follows:

1. Ninik Mamak and his nephew are not allowed to plant oil palm across the shores of Lake Bakuok.

2. Ninik Mamak and his nephew are not allowed to make cages along the waters of Lake Bakuok, for those who have already made cages, they are only given one harvest permission.

3. Ninik Mamak or his nephew is strictly prohibited from poisoning and electrifying fish along the waters of Lake Bakuok. 
From the interview results, it can be seen that in the case of management of Lake Bakuok entirely delegated to the village and ninik mamak, the role of the Tourism Office of Kampar Regency is only as a bridge and promote every activity in Lake Bakuok such as the Maawuo event, because the lake is only managed when there is needs and interests just like at the Maawuo event.

In addition, based on observers' observations in the field there are no definite and strong rules regarding violations and sanctions given to the community if they violate existing rules, because there are still people who catch fish carelessly, on the banks of the lake there are still many palm trees and fish cages. the people in the lake, besides the surface of the lake are also overgrown with bushes such as untreated.

\section{Conclusion}

Based on research and discussion conducted by researchers in Aur Sati Village, Tambang Subdistrict, Kampar Regency, it can be concluded that Ninik Mamak has a significant role in the management of Lake Bakuok in Aur Sati Village, all decisions or rules are made based on the mamak ninik agreement in Tambang District.

\section{References}

Agustino, Leo, 2016, Dasar-Dasar Kebijakan Publik, Bandung: Alfabeta

Alikodra, Hadi S, 2012, Konservasi Sumber daya alam dan Lingkungan, Yogyakarta: Gadjah Mada University Press

Amin Ibrahim, 2004, Pokok-Pokok Analisis Kebijakan Publik, Mandar Maju, Bandung.

Amirullah, dkk. 2003. Perilaku Organisasi. Malang : Bayumedia

Budi Winarno, 2007, Kebijakan Publik Teori dan Proses, Penerbit Media Pressindo, Yogyakarta. Buwono, Y.R, 2017, Identifikasi dan Kerapatan Ekosistem Danau Bakuok Di Kawasan Teluk Pangpang Kabupaten Banyuwangi, Samakia: Jurnal Ilmu Perikanan, Volume 8,No. 1, April 2017, ISSN:2086-3861, E-ISSN: 2503-2283.

Djamal Irwan. Zoer'aini, 2017Prinsip-Prinsip Ekologi, Jakarta: Bumi Aksara

Edi Suharto, 2005, Analisis Kebijakan Publik, Alfabeto, Bandung

Gary N.McLean, Organization Development; Principles - Processes - Performance, Barrett Koehler Publishers,Inc. San rancisco, 2006, h. 6. 
Ghufron H. Kordi K.M, 2012.Ekosistem Danau Bakuok: Potensi, fungsi dan pengelolaan, Jakarta: Rineka Cipta

Gibson, Ivancevich, Donnelly, Organisasi; Perilaku, Struktur, Proses, Erlangga, Jakarta, 1996, h. 238.

Gibson, Ivancevich, Donnelly, Organisasi; Perilaku, Struktur, Proses, Erlangga, Jakarta, 1996, h. 243.

Gumilar. I, 2012, Partisipasi Masyarakat Pesisir dalam Pengelolaan Ekosistem Hutan Danau Bakuok Berkelanjutan di Kabupaten Indramayu, Jurnal Akuatika, vol. III No. 2 / September 2012 (198-211) ISSN 0853-2523

Muhtadi Rangkuti, Ahmad dkk, 2017,Ekosistem Pesisir dan Laut Indonesia, Jakarta: Bumi Aksara

Mulyanto Sumardi. 1982. Sumber Pendapatan Kebutuhan Pokok dan Perilaku

Purnobasuki, H. 2005. Tinjauan Perspektif Hutan Danau Bakuok. Penerbit Airlangga University Press. Surabaya.

Senoaji. G, 2016, Peranan Ekosistem Danau Bakuok di Pesisir Kota Bengkulu dalam Mitigasi Pemanasan Global Melalui Penyimpanan Karbon, Jurnal Manusia dan Lingkungan, Vol. 23, No. 3, September 2016: 327-333

Setyawan AD, Winarno K dan Purin CP. 2003b. Ekosisitem Danau Bakuok di Jawa: Restorasi. Jurnal Biodiversitas Vol. 4 (2).

Setyawan. A, dkk, 2006, Pemanfaatan Langsung Ekosistem Danau Bakuok di Jawa Tengah dan Penggunaan Lahan di Sekitarnya; Kerusakan dan Upaya Restorasinya, Jurnal BIODIVERSITAS Vol. 7, No. 3, Juli 2006, hal. 282-291

Sigit, Soehardi. 2003. Perilaku Organisasional. Yogyakarta : BPFE UST

Stephen P. Robbins \& Mary Coulter, Manajemen, Prenhallindo, Jakarta, 1999, h.360.

Supriharyono. 2007. Konservasi Ekosistem Sumber Daya Hayati di Wilayah Pesisir dan Laut Tropis. Pustaka Pelajar. Yogyakarta.

Totok Mardikanto dan Poerwoko Soebiato, 2015, Pemberdayaan Masyarakat dalam Perspektif Kebijakan Publik, Alfabeta, Bandung.

Utomo. B. dkk, 2017, Strategi Pengelolaan Hutan Danau Bakuok Di Desa Tanggul Tlare Kecamatan Kedung Kabupaten Jepara, Jurnal Ilmu Lingkungan, Volume 15 Issue 2 (2017) : 117-123 ISSN 1829-8907 
Wardhani, M.K, 2017, Kawasan Konservasi Danau Bakuok: Suatu Potensi Ekowisata, Jurnal KELAUTAN, Volume 4, No.1 April 2011 ISSN : 1907-9931

William J. Rothwell \& Roland Sullivan, Practicing Organization Development, John Wiley \& Sons, Inc. San francisco, 2005, h. 1 dan 12

William N Dunn, 2003, Pengantar Analisis Kebijakan Publik, Penerbit Gadjah Mada University Press, Yogyakarta. 